$$
\begin{gathered}
\frac{\text { 総 }}{\text { 説 }} \\
\text { 遅発性内リンパ水腫について } \\
\text { 一特にメニェール病との関連一 } \\
\text { 亀井 民雄・渡辺 健二* }
\end{gathered}
$$

\title{
A Review of Delayed Endolymphatic Hydrops
}

\author{
Tamio Kamei \\ (Maebashi City) \\ Kenji Watanabe \\ (Kiryu-Kosei Hospital)
}

\begin{abstract}
Delayed endolymphatic hydrops (DEH), a disease entity that can be differentiated from Ménière's disease, typically develops in patients who have experienced a profound, long-term hearing loss in one ear. This condition was first reported by Kamei et al. ('71), who indicated that it occurred in about $20 \%$ of patients who had had unilateral profound deafness since early childhood (UPDC), and it appeared at various stages of adulthood, during or after puberty. Wolfson and Leiberman ('75) and Nadol et al. ('75) reported other types of unilateral profound deafness causing this condition that were due to viral and bacterial labyrinthitis, head trauma, or sudden deafness. Schuknecht ('78) defined DEH and classified it into two types: the ipsilateral type, in which vestibular symptoms identical to the vestibular symptoms of Ménière's disease develop in a previously deafened ear, and the contralateral type, in which a fluctuating hearing loss and/or vestibular symptoms develop in the hearing ear. The underlying pathophysiologic mechanism for the development of $\mathrm{DEH}$ has been explained as progressive endolymphatic hydrops in the inner ear due to delayed atrophy or fibrous obliteration of the endolymphatic resorption system, resulting from a previous inner-ear injury. In the ipsilateral type, episodic vertigo is not usually accompanied by fluctuating hearing levels and tinnitus because the hearing loss is profound. The period between the onset of pre-existent deafness in one ear and the onset of $\mathrm{DEH}$ ranges from several months to 74 years. The cause of the pre-existent deafness is UPDC in more than half of the cases of both types of DEH. Almost all kinds of other degenerative disorders of the inner ear are mostly due to inflammation (viral and bacterial) and trauma (physical and acoustic). The ipsilateral type of DEH is more frequently seen than the contralateral type. The onset age of the contralateral type is higher, in general, than that of the ipsilateral type. Medical treatment may be effective for both types of DEH. Complete relief from episodic recurrent vertigo may be expected in $65 \%$ of cases within 5 years after the onset of vertigo and in $90 \%$ of cases within 10 years. Labyrinthectomy or vestibular nerve section in the deaf ear is curative in the ipsilateral type, but no satisfactory surgical therapy is available for the contralateral type of the disease. The audiological definition of DEH by Schuknecht seems, however, to be somewhat arbitrary, as the patients' symptoms form a continu-
\end{abstract}


ous spectrum with other Ménière's syndrome cases, occurring in association with less-marked degrees of sensorineural hearing loss. The existence of the contralateral type of DEH due to UPDC, which often shows typical symptoms of Ménière's disease, seems to suggest that Ménière's disease may occur as a delayed sequela of subclinical damage of the inner ear, especially damage sustained in childhood.

Key words : delayed endolymphatic hydrops, unilateral profound deafness, ipsilateral type, contralateral type, labyrinthectomy

はじめに

高度な内耳性難聴が長年月続くと，反復する回転性め まいが生じ, メニェール病様の臨床症候が発現すること がある．原因が去っても内耳の組織変化が遺残すると， 膜迷路に二次的に進行性内リンパ水腫が生じてくるため と考兄られる。本症は遅発性内リンパ水腫 (delayed endolymphatic hydrops, 以下 DEH) と呼ばれる1).

本症は1971年筆者ら ${ }^{2)}$ が，生下時または乳幼児期に発 現したことが推定される以外には原因も発症時期も不詳 な，片耳の高度な感音難聴3～７（以下，若年性一側䆍）に 遅発性に発症する特異なめまいとして報告した。遅発性 めまいの発現率は約 $20 \%$ (44中 9 例)であった，次いで

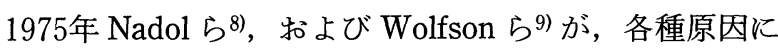
よる一側襲にも同様なめまいの発現を認め症候群として 報告した．彼らの報告した一側襲は合計すると，ウイル 又性内耳炎 7 例, 細菌性内耳炎 2 例, 頭部外傷 2 例, 突 発性難聴 1 例括よび，先天性ないし原因不明な難聴（お。 そらく若年性一側襲に相当) 5 例であった(計17例)。こ のめまいは1976年 Schuknecht ${ }^{10)}$ により膜迷路の delayed hydrops と考察され，1978年1)，一臨床的疾患単位とし てのDEH と命名された。しかしながら，本症の内耳の 組織学的知見の蓄積はいまだ乏しい。

DEH は今日では主として, 高度難聴耳に発現する同 側型 (ipsilateral type) と, 対側の良聴耳に発現する対側 型 (contralateral type) 飞大別される1111)。本症の回転性 めまい発作はメニエール病の前庭症状とほとんど区別が つかないが，典型例では他の臨症所見より診断は困難で はない.しかし, 同側型の非典型例や対側型では, メニ エール病との鑑別が問題になる．本稿では DEH の全体 像について記述し，メニェール病との接点について言及 する.

\section{DEH の診断}

診断基準が確立されているのは, 同側型と対側型であ

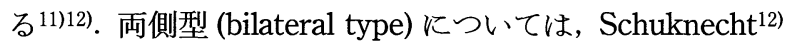
の定義が必ずしも明確ではないと考㝋ている.

典型的な症例では同側型, 対側型とも, 初期相 (early phase) ${ }^{11)}$ ，すなわち最初の内耳障害の過程で，1 耳が高 度な感音難聴になった点が共通している。 その際, 難聴 の原因の如何は問わない，これに対して後期相 (late phase) ${ }^{11)}$ ，すなわち遅れて内リンパ水腫が発現する過程 そ执いては, 両者の臨床症状は異なる. 典型的な症例の 診断基準は以下のごとくである.

1. 同側型 $\mathrm{DEH}$

1) 1 耳が高度感音難聴ないし全壟(以前より存在)(初 期相).

2) x = ール病様前庭症状(自発性発作性回転性め まいの反復と, 嘔気や嘔吐など自律神経症状の随伴)の 発現(後期相).

3）めまい発作時に聴力変動は不随伴.

4 ）中枢神経症状の欠如.

同側型は聾耳に進行性内リンパ水腫が発生する結果, 反復性発作性めまいが発現し, しかもその際難聴の変動 は伴われず，耳鳴も多くの例で存在しな(228)13)。この理 由はめまいの患耳に颃いて，すでに聴覚が高度に破壊さ れているためである。しかし，一部の症例ではめまい発 作時に耳鳴の出現ないし変化や，耳閉ないし耳厈迫感の 出現を認めることがある ${ }^{899}$. 耳鳴の変動は扣とらく聴 覚の残存に依拠し, 耳閉感は内リンパ水腫の存在を示唆 すると思われる.な拉，めまい発作は数10分から数時間 続く回転性めまいが多く, ふつらメニエール病の前庭症 状と区別しがたい(28)911113)。 しかし，ときにめまいの持 続が 1 日以上と長く続き13), 典型的なメニエール病とは 異なるとの印象が持たれることがある.

\section{2 . 対側型 DEH}

1) 1 耳が高度感音難聴ないし全壟(以前より存在)(初 期相).

2 ) 他耳(良聴耳)に新たに内耳性難㯖が出現(後期相). 
3 ）良聴耳聴力が変動.

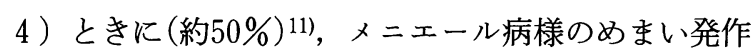
が出現.

5 ) 中枢神経症状の欠如.

対側型では後期相に打いて, 進行性内リンパ水腫が良 聴耳 (多くは元来聴力正常) に発生し, 良聴側の変動性聴 力障害, 反復性発作性めまい，または両者の合併症状が 出現する．めまいを合併するものでは, 良聴耳メニエー ル病との区別が困難なことが多い11113) 15)。な拈，Schuknecht ら ${ }^{11)}$ によれば，一般に対側型に括いては良聴耳 が温度刺激に対して無反応を示すものが $39 \%$ と多く, こ のことが対側型 DEH の多くに括いて良聴耳の聴力変動 のみが出現し, 回転性めまいなどの前庭症状を伴ら症例 が少ないことの理由であるといら。

以上, DEH の 2 病型の頻度に関しては, 報告者によ り相違がある. Schuknecht ら ${ }^{11)}$ や渡辺ら ${ }^{14)}$, Hicks ら ${ }^{16)}$ は, 同側型, 対側型注涪同数としたが, 筆者らの 統計では若年性一側襲に起因する DEH ではその $89 \%{ }^{13)}$, また，各種疾患に起因する DEH 全体でもその $87 \%{ }^{17)}$ が 同側型であり, 残りが対側型である. 工藤ら 18$)$ の症例 でも同側型 $78 \%$, 対側型17\%，両側型 $5 \%$ であった。 かの報告でも同側型のみを報告しているか，あるいは同 側型が多いとするものが多(189919) 24). な拉, 初期相か ら後期相出現までの期間は， $1 \sim 74$ 年と広範囲にわた $3^{8) 111}$.

\section{3. 両側型 DEH そついて}

Schuknecht ${ }^{12)}$ とよると両側型 DEH は, 初期相にお いて両側性ウイルス性神経迷路炎の結果として, 両耳の 聴覚, 前庭, またはその両者の機能低下 (ただし機能の 一部は残存)が発来し, 後期相に扣いて両耳に進行性内 リンパ水腫症候(変動性聴力障害, めまい, またはとの 両者)が発現した場合としている. しかし, 初期相の原 因疾患をウイルス性神経迷路炎のみに限定することにつ いては議論の余地があり, また, 初期相の聴力障害の程 度についても箃密な規定を欠いているので, 疾患概念に 混乱が生じやすいと考兄られる。したがって筆者は，も 乙両側型を定義するならば, 両耳それぞれに DEH が発 生した場合，換言すれば両耳ともに同側型が発現したか （ただし発症の時期はずれてもよい，あるいは 1 耳に同 側型, 他耳に対側型が合併した場合とするのがよいと考 えている.しかし，そのよらな症例は実際にはまれと推 定される。一方, 工藤ら ${ }^{18)}$ は DEH 全体の $5 \%$, 沢田
ら25)は23\%に両側型を認めたとしている.

\section{4 . 診断上の問題点}

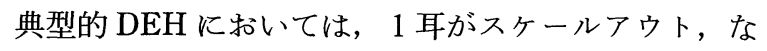
いしわずかに残聴を残す程度の高度感音難聴を示す非対 称性聴力障害が通例であるが, 先行する感音難聴の程度 をどの位に設定すべきかについては，な敃議論が残され ている. Langman ら ${ }^{26)}$ は平均聴力で $70 \mathrm{~dB}$ 以上, 沢田 ら ${ }^{25)}$ は $50 \mathrm{~dB}$ 以上の一側高度難聴として, DEH 症例の 調査をしている．難聴の程度を低く設定すればするほど， 遺残している内耳組織の変化が軽微である可能性があり, したがって DEH を起こしにくくなると同時に，そのよ らな症例に执いてはDEHがますをすメニエール病と区 別しにくい症状を呈するであろらことが考兄られる211. たとえば，Karmody ${ }^{27)}$ が報告した先天性難聴に起因し た DEH 4 例中，中等度難聴を示した 1 例にこのような 症例をみることができる．また，音響外傷や頭部外傷後 に遅発性にめまいや聴力変動をきたす症例にも，同様な 症例が多くみられる28) 30). DEH の対側型はこの極端な 場合で, 以前は難聴を認めなかった耳に変動性聴力障害 が生じ，また，めまいが発症するのであり，その多くは 臨床症候的に良聴耳メニェール病との区別が困難であ

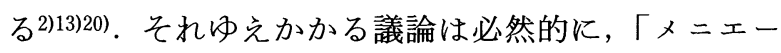
ル病の一部は広義の DEH ではないか」との命題に発 展する、筆者はこのことへの解答を得るために，当面は DEH の臨床診断をできるだけ典型的な症例に限定 し，その臨床像をより一層明確にするのがよいと考兄て いる.

\section{DEH の成立機転}

Nadol $5^{8)}$ は本症 (同側型) の病態生理を内リンパ水腫 と考察したが，その直接的根拠は次の 2 点であった。 a 迷路破壊術時のアブミ骨底の穿刺 (diagnostic labyrinthotomy) で得られた底板直下の穿刺液が，正常内リン パと同一の生化学的組成を示した ( 2 例). b . 迷路破壊 術時に採取したアブミ骨の組織学的検索に执いて，底板 内面に膜迷路の付着が認められた（1例）。これらの所見 はいらまでもなく膜迷路, ことに球形囊の水腫を示唆し ている. LeLiever ら ${ }^{23)}$ も後年, a の所見を 5 例で確認 している.

Schuknecht ${ }^{10)}$ は上記の所見に基づき， DEH（同側型） の成立機転につき次の仮説をたてた，すなわち，高度難 聴を示す陳旧性病変を有する内耳に括いて, 内リンパ吸 
収系である内リンパ襄，あるいはその導管である内リン パ管に，二次的変化としてそれぞれ萎縮，あるいは線維 性閉塞などが生じ，その結果として次第に進行性内リン パ水腫が形成される.そしてその際臨床症候の出現には, 聴覚機能が高度に破壊されている反面, 迷路機能が完全 には失われていないことが必要な条件であるとした．こ の仮説は DEH の臨床像をよく説明するが，このことを 直接証明する人の側頭骨の病理組織学的研究はまだない. この点 Yaku ら ${ }^{31)}$ は, 16 歳および27歳の 2 女性に行わ れた，若年性一側襲に起因したことが考えられる同側型 DEH の経迷路的前庭神経切断術時に採取した内耳組織 の電顕的検索に颃いて, 前庭感覚器 ( 3 つの膨大部稜と 卵形囊斑)，拉よび前庭神経節に特別な変化を認めてい ない，彼ら ${ }^{311}$ の研究に抽いて前庭の他の部分，および 蝸牛の所見は未検索のため不明であるが，少なくともこ れらの例に拁いて, 前庭部の感受機構は十分に保たれて いたことが考えられる.

対側型の成立機転については, 筆者ら ${ }^{13)}$ は, 初期相 に括いて良聴側の内耳に難聴側と同じ原因による軽微な, しかし臨床症状を呈さない潜在的な組織変化が生じて遺 残して打り，その結果長年月経過後に良聴耳に進行性内 リンパ水腫が発生してくる可能性を指摘した．その根拠 は，一つは DEH を合併していない若年性一側襲に括い て，良聴耳が温度眼振反応の低下を示すことがあること である、たとえば Tarkkanen ら³) は26\%(27中 7 例)， 筆者ら ${ }^{13)}$ は $5 \%$ (22中 1 例), Everberg) は $2 \%$ (122中 2 例)に沶いて，めまいなき若年性一側䆍の両耳に低反 応を認めている．このことは明らかに，少なくとも若年 性一側襲に招いては, 初期相時に良聴耳にも, 高度難聴 耳と同じ障害が波及している場合があることを示唆して いる. さらに渡辺ら ${ }^{14)}$ は, 初期相の原因が若年性一側 襲に限定されない $\mathrm{DEH}$ 全般についての分析に执いても， 両耳に反応低下を同側型の $10 \%$ (10中 1 例), 対側型の 30 $\%$ (10中 3 例) 飞認めている. また工藤ら ${ }^{32)}$ は同側型 DEH に招いて，患耳の $82 \%$ (28中23例) に反応低下を認 める伍か，対側耳にも $11 \%$ (28中 3 例)に反応低下を認め ている。これらのことは一側壟全般に扣いても, 良聴耳 が高度難聴耳と同じ原因により潜在的な障害を受けてい たであろらことを示唆していると思われる。そしてこの 仮説は, Schuknecht ら ${ }^{11)}$ により一つの実証を得ている.

すなわち, Schuknecht ら ${ }^{11)}$ は，幼児期から存在した 原因不詳な一側壟(本稿に特ける若年性一側壟に該当す
ることが考えられる)に発症した 2 例の対側型 DEH の 側頭骨の病理組織学的検索に打いて，両例に共通して壟 耳にウイルス性内耳炎の後遺症を示唆する内リンパ水腫 を伴ら膜迷路の変性所見と, 対側耳にメニエール病に一 致する内リンパ水腫の所見を認め, これらのことから初 期相時に 1 耳がウイルス感染を受け襲となった時期に, 対側耳も潜在的なウイルスの軽い感染を受け，それを基 礎に良聴耳にメニエール病と同じ組織変化が生じたもの と考察している. Schuknecht ら11)によればいわゆる小 児の一側襲は，ウイルス性内耳炎が主な原因であり，そ の際対側耳も軽微なウイルス感染を受け，それを基礎に 対側型 DEH が発現し得るといら.

\section{検 查}

1. 聴力検查

$\mathrm{DEH}$ の確定診断には，少なくとも 1 耳が全䆍ないし 高度感音難聴であることを証明する必要があり，このた め純音聴力検査が本症の臨床検査として不可欠である。 対側型が疑われる場合には，さらに良聴側聴覚の補充現 象証明のため，SISI 検査や自記オージオメトリーなど を実施する．また，頻回の聴力検査により良聴側の聴力 変動の有無を確認する．蝸電図検査は同側型の襲耳には 一般に無反応となり応用できないが，対側型の良聴耳で はメニェール病の患耳と同様に, 一SP/AP 比の増大(陽 性所見)が $60 〜 70 \%$ の症例に認められる2023).

\section{2 . 眼振検査}

めまい発作時には，水平回旋混合性の自発眼振が観察 される．また，非発作時にしばしば水平回旋混合性の頭 振り眼振が誘発され，内耳障害の診断の参考になる。 し かし，DEH ではメニエール病に似て，眼振方向は患側 向きのことも，またとの逆向きのこともあるので，眼振 所見からのめまいの患側診断には注意を要する13). 一方 Parnes ら ${ }^{34)}$ は，めまい発作時に良聴側向きの麻痺性眼 振に続き, 強い回旋性の患側向き眼振が逆転して出現す ることがあり，この変化の観察が患側の同定に参考にな るとしている。

\section{3 . 温度眼振検査}

一般に内耳性めまいに扮いては, 温度眼振反応の低下 はその側がめまいの患側であることを意味する。しかし， DEH の原因として最も頻度の高い若年性一側壟では, $\mathrm{DEH}$ の合併を認めない場合でも壟耳側に 2845)～56\%33 に温度眼振反応の低下が認められるので, 襲耳側の反応 
低下が必ずしもめまいの患側を意味しない13)。また，若 年性一側壟では DEH を合併しない場合でも，上述のご とく良聴側も一部 $(2 \sim 26 \%)$ )温度眼振反応の低下を示 寸場合があるので34)，良聴側の反応低下といえども必 ずしも患側を意味しない13)。もとより，一般に温度眼振 反応が正常であっても，常に患側を否定するものではな い.ささに，初期相の原因が若年性一側壟に限定されな い DEH 全体についてみても，上述のごとく両耳の反応 低下が同側型の $10 \%$ ，対側型の $30 \%$ 亿認められ ${ }^{14) ， ま た ~}$ 同側型 DEH に和いて反応低下が患耳の $82 \%$ のほか，対 側耳にも11\%に認められる32)。以上より DEH に扒いて， 温度眼振検査は必ずしも常に患側の推定に大きく役立つ とはい党ない(19220).

4.グリセロールテスト，フロセミドテスト

これらの検査は内リンパ水腫の推定に役立つが，グリ セロールテストは DEH 例では主として対側型が検査対 象になる1435336)。これに対してフロセミドテストは同側 型, 対側型とも検査対象となるが32), 対側型では温度眼 振反応がしばしば両側とも高度に低下して拉り，かかる 症例ではこの検査は実施が困難になる18).

\section{DEH の鑑別診断}

$\mathrm{DEH}$ は進行性内リンパ水腫10)をきたす次の 2 疾患や, 一側高度感音難聴をきたす聴神経腫瘍との鑑別が必要で ある。

1.メニエール病

メニェール病は特発性内リンパ水腫が本態であり 3738 ), 元来, 聴力正常な耳に発症することに留意する. なた, メニエール病だけでは，1 耳が高度難聴ないし襲になる ことはほとんどないことも鑑別診断上の参考になる.こ れに対して DEH では, 原則として 1 耳が高度感音難聴 (陳旧性)であることが診断上の必要条件である.

ただし，対側型でめまい発作が伴われる場合は，良聴 耳にメニェール病が発症した可能性を否定するのは症候 的に困難なことが多(13)14). しかし，これを筆者ら13)の 若年性一側襲についての統計でみれば,メニエール症状 を伴う良聴側 DEH の発症率は $3 \%$ (89中 3 例)であり， したがって若年性一側壟の健耳にメニエール病が偶然に 発生したにしては明らかに高率である.このことから少 なくとも若年性一側壟の対側耳に発症するメニェール症 候については，原則的に $\mathrm{DEH}$ とみなすべきと考光てい る.

\section{2 . 迷路梅毒}

ことに先天性遅発性迷路梅毒例では続発性内リンパ水 腫を合併しやすく39), しかもめまい発作がメニエール病 に類似するため鑑別の対象になる，梅毒血清反応陽性， 他種梅毒症状(びまん性角膜実質炎, またはその後遺症 など)の存在が診断の参考になる。

\section{3 . 聴神経腫瘍}

聴神経腫瘍でメニエール病様めまい発作を反復するも のは少ないが，一側高度感音難聴 (対側聴力正常)を呈す る場合が多いので，ことに同側型 DEH との鑑別が必要 であり，積極的に MRIなどによる小脳橋角部の画像的 検索を実施する．若年性一側襲に合併する DEH では， ふつら, 高度難聴耳に耳鳴が訴えられな(225)13) ことも 鑑別診断の参考になる.

\section{DEH の初期相の原因}

初期相すなわち高度難聴の原因は, 若年性一側襲が多 (2211116)1719)24)32)、筆者ら 17)の最近の統計では, 若年性一 側壟が $\mathrm{DEH}$ 全体 (77例) に占める割合は $52 \%$ であり，ま た Schuknecht ${ }^{11)}$ の統計 (62例) でも，同側型，対側型と も若年性一側壟が過半数を占め, $\mathrm{DEH}$ 全体の $68 \%$ に達 している. 工藤ら ${ }^{18)}$ の対側型 7 例でも， 4 例 $(57 \%)$ が 若年性一側壟である．報告者により差があるが，次いで 中耳炎性内耳炎1617) やウイルス感染 (ムンプス性, 麻疹

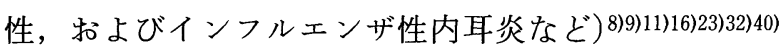
が多く, そのほかでは音響外傷1728)29), 頭部外傷1124)29932), 乳様突起炎 ${ }^{16)}$, 細菌性内耳炎 (髄膜炎あるいはジフテリ アによる) ${ }^{1124)}$, 突発性難聴811132), アブミ骨切除術26), 猩紅熱16)などが先行難聴の原因として知られている. また，両側性先天性難聴もDEH の原因耳になり得る27).

\section{DEH の発症頻度}

先行する難聴の原因の相違により, DEH の発現しや すさに相違があるかについては，まだほとんど報告を認 めない，しかし，若年性一側襲についての筆者らのアン ケート調査によれば，めまいの合併なき症例が難聴を主 訴に受診したのち，10 20(平均 15 ) 年以内に $\mathrm{DEH}$ が 17

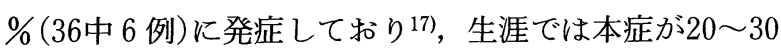

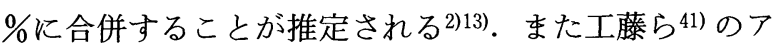
ンィート調査によれば，めまいなき若年性一側龍患者の 受診後平均 10 年で, DEH の発症が $14 \%$ (28中 4 例) 飞み られたという。 
DEH の人口に和ける頻度については，筆者は次のよ らに推定している. 若年性一側襲に括ける DEH の生涯 に和ける発現率は，上記のごとく約25\%2113) である。一 方, 若年性一側壟の人口に郝ける罹患率は, Everberg ${ }^{4)}$ やTarkkanen ら ${ }^{3)}$ の学童での調査によれば，それぞれ $0.1 \%$ (デンマーク), 拉よび $0.09 \%$ (フィンランド)であ る. また他方, 若年性一側壟が先行難聴として DEH 全 体の中に占める割合は, 既述のごとく約過半数である. したがって大約, 人口 1 万人に 5 人程度の人が, 生涯の らちに DEH に罹患する可能性があると推定される。一 方, メニエール病の有病率は, 国, 地域, 報告者により 差があるが，拉よそ人口 1 万人当たり本邦で1.5 2.5 人 ${ }^{42)}$ ，スウェーデンで4.6人到である.すなわち DEH の発現率は、メニ土ール病のそれに匹敵する值である. な拈，診療機関からの統計では，渡辺ら ${ }^{14)}$ の経験では $x=ェ ー ル$ 病確実例と DEH の比は 7 対 1 , 工藤ら ${ }^{41)} の$ 統計ではこの比は12対 1 であり，また Harcourt ら ${ }^{21)}$ が 9 年間に経験した各種原因による全メニェール症候394 例中では，DEH は7.9\%に相当したという。

\section{後期相の初発年齢}

後期相すなわち $\mathrm{DEH}$ の初発年齢は, 全体として11〜 20 歳と $41 \sim 60$ 歳に山がある ${ }^{17)}$ が，前者は主として若年 性一側襲によるものである. 特に若年性一側壟でみられ る同側型は, 理由は明らかではないが 2 相性発症を示 し20132)，これに対して対側型は中年以降の年齢で発症が 多い傾向がある20). この後者の理由としては, 初期相に 拊ける良聴側の内耳障害が高度難聴耳に比べて軽いこと が考兄られる. 先行する高度難聴が若年性一側聾以外の 原因による DEH では，発症までに遅延があるので20歳 以後の発症が多(、17)23).

初期相の発症から後期相開始までの期間(発症潜時)は 幅が広く，既述のごとく $1 \sim 74$ 年にわたっている. しか し，頭部外傷に起因するもののなかには，もっと短期間 でDEH が発症するものがあるよらである．Paparella ら 29)によれば，音響外傷後に内リンパ水腫様症状ない しメニェール症候が発現したものは, 全例(18例)で発症 潜時が 1 ２0年であったが，側頭骨骨折を伴わない頭部 外傷例で DEH 症状を発現したもの(19例)では，その約 3 分の 1 ( 7 例) で受傷後 1 カ月以内にメニエール症候が 出現したという．この発症潜時は初期相の原因と無関係 とする報告32) もあるが，筆者らの経験では突発性難聴

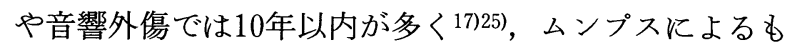
のも20年以内と比較的早( ${ }^{199}$. 一方, 若年性一側壟や中 耳炎性内耳炎に起因するものでは，発症潜時はさまざま であり，長いものでは50年以上の症例がある 1720225)。発 症潜時は招そらく, 初期相に括ける内耳障害の程度, 局 在, 病態の種類などによって影響されると思われ，初期 相の原因とある程度の関連はあるのではないかと推測し ている.

\section{後期相のめまいの予後}

筆者らのアンケートによる DEH 例の追跡調査 ${ }^{17)}$ では, 同側型, 対側型の如何にかかわらず，保存的(薬物)治療 のめまいの予後は長期的には悪くはなく，5年以内に 65 $\% ， 10$ 年以内に $90 \%$ が寛解を得ている. しかし，一般に 寛解までに長期間を要することが，DEH の臨床上の大 きな問題点である.

\section{DEH とメニエール病との接点}

メニェール病の概念に関して, 世界の研究者間で大き な見解の相違が認められる ${ }^{38)}$. その結果診断名として, 大別して, 主としてメニェール症候(群)，メニェール病 (特発性発症), 特発性内リンパ水腫の 3 種が使用されて いる，一方，これらのどの診断名を用いるにせよ，本症 の発症病理を進行性内リンパ水腫に求める点では, 注湆 全世界の研究者の見解の一致をみている. 意見の基本的 な相違点は, メニエール病を特発性を含めて多病因性疾 患と考学るか，あるい恃発性発症を示すもののみに 限定するかである. 本邦の厚生省特定疾患メニエール病

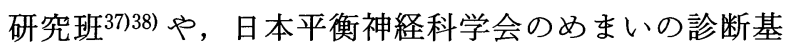
準化委員会4) そ括けるメニエール病の診断基準では, この後者の立場をとって拈り，したがって DEH はメニ エール病に該当しない，またこれらの基準に扒いては, 蝸牛症状の変動とめまいの反復の両方がともに存在する ことがメニェール病 (確実例)の診断の必要条件とされる ので，典型的な同側型 DEH はこの点からも該当しない．

しかしながら, 先行する難聴が全壟, ないしそれに近 い高度な感音難聴ではなく,より軽度な難聴25)，乙かも ことに無自覚的な内耳障害から同側型の DEH が発生し てくる可能性は容易に考兄られる. そしてこの場合には， $\mathrm{DEH}$ が臨床症候上メニエール病と区別できないことも あり得ることが考学られる。実際，回転性めまい発作を 伴う対側型 DEH では， ほとんどの場合メニェール病と 
の区別がきわめて困難である1314)。このよらなことから $x=ェ ー ル$ 病の成因に関して, 過去の軽微な, 無自覚性 の内耳障害に起因する DEH である場合があるのではな いか，との推論が成立し得る.

武田ら ${ }^{20)}$ によれば，若年性一側襲に起因する DEH の 場合，同側型では15２5歳あたりに発症の大きな山があ るのに対して，対側型ではそれが40～50歳と中年期の方 へずれている. 各種の原因による一般の対側型 DEH の 場合でも, 発症年齢の多くは40歳以後と同側型の場合よ

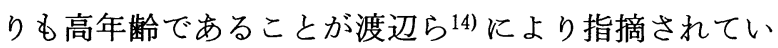
る. 打とらくこれらの場合も，一般に良聴耳の内耳障害 が高度難聴耳のそれよりる軽いためと考兄られる。 メ二 エール病に执いて若年期発症はまれであるが，この理由 についても，もしメニェール病が軽微で subclinical な 内耳障害に起因する DEH として発症すると仮定するな らば理解は容易である。

$\mathrm{DEH}$ とメニェール病の発生病態は, 本質的に同一で はないかとの見解が次第に広まりつつあるようにみえる。 たとえば Paparella ら 29) は, 音響外傷や, 明らかな側頭 骨骨折を伴わない頭部外傷後の遅発性めまいが，一般に メニェール病と区別しにくい臨床症状を呈すること，ま た側頭骨外傷後の遅発性めまいの 1 例で, 内耳の組織学 的変化がメニエール病と全く区別できない内リンパ水腫 所見を示したことなどから，すべてのいわゆる “特発性” メニエール病は, 結局は何らかの原因によるメニエール 症候ではないかと考察している。また Schuknecht ら ${ }^{11)}$ は, メニェール病は何らかの内耳障害, ことに小児期の 無自覚性内耳障害(彼らはそれをウイルス性内耳炎と推 測している)の漣発性続発症と推定している.さらに $\mathrm{Baloh}^{45)}$ は, DEH をメニエール病の一病型とみている. 筆者らは, DEH とメニェール病は本質的に重複する部 分があると考えている.

\section{DEH の治療}

保存的治療が原則であり，まず $3 \sim 6$ カ月間24) はメ ニェール病に準じた薬物治療, たと学ば適宜に循環改善 剤(シンナリジン, カリジノゲナーゼなど), 鎮暈剤(塩 酸メクリジン, メシル酸ベタヒスチンなど), 安定剤(メ キサゾラム，ジアゼパム，クロルジアゼポキシドなど)， 利尿薬(浸透圧利尿剤のイソソルビド20)，ヒドロクロロ チアジドのダイクロトライド30)など)，あるいはステロ イドなどの投薬, ならびに減塩療法を行ら。一般に本症
は保存的療法に抵抗するものが多く, メニエール病以上 に治療が困難である17191921)。しかし，ときに自然に寛解 し，また長期的には発作から解放されることが少なくな (、17)22) ことに留意する.

薬物治療で寬解をみない場合，手術的治療が適応とな る.この場合, 同側型では最終的には(経鼓室的, 経乳 突的)迷路破壊術1889911116)23224226)46)，(経迷路的)前庭神経 切断術1922126)311 などがきわめて有効である。しかしその 前に, 機能保存的な内リンパ霊開放術 (Portmann 手術) を試みるのも取るべき選択である16)32)。というのは特に 若い患者の場合，そうすることにより将来万一人工内耳 手術が必要になるような場合, その可能性が保存され得 る16). 手術準じる治療法として, ゲンタマイシンやス トレプトマイシンの鼓室内注入が有効なこともある22). な拉, 患耳の迷路機能が良好な場合は, 術後の平衡障害 が高度になることがあるので35)，同側型 DEH であって も，特に高齢者では安易に破壊手術を行ってはならない。 対側型 DEH に対しては，迷路破壊術は全聴覚機能を 喪失させるので，原則として行ってはならない，そして もし対側型で手術的治療が必要な場合には, 内リンパ囊 開放術や，その活かの減荷術など16)18223)，メニエール病 に準じた機能保存的手術が考慮されるべきである，ただ しこの場合，術後経過はめまい，難聴とも必ずしも常に 満足すべきものではない18)。しかし他方，内リンパ霊開 放術により聴觉が全く失われる可能性は注淁 $2 \%$ 以下と い5 ${ }^{16)}$. 対側型に対し後迷路法に上る前庭神経切断術は, 一応，理論的に適用性があるが，聴覚への長期予後は不 明な点が多く，必ずしも勧められない16)。またこの手術 法では, 生命への重大な術時合併症の発生の可能性も皆 無とはいえない。

おわりに

DEH は同側型, 対側型とも, 臨床に定着した疾患概 念になりつつあるが, 当面, 2 つの大さな問題点がある. 第一は，両側型をより明確に定義づけることであり，第 二は, 初期相に扣ける難聴, 寸なわち先行難聴の程度を どう基準づけるかである. 前者に関して, 本稿で筆者ら は私案を述べた。後者に関しては, 現在の全壟ないし高 度感音難聴を, もっと軽い難聴, すなわち中等度難聴を で拡大してもよいのではないかと考学ている。しかしな がら，先行難聴に対するこれまでの厳しい基準は，疾患 概念の形成に大きく役立ってきたことは事実である. 
先行難聴の程度を，もっと軽いものまで含めるべきだ とする考えは, DEH の本態論的立場からの発想である. 高度難聴と中等度難聴を区別すべき理由は，二次的に遅 発性に内リンパ水腫をさたす原因としては存在しない. しかしそらなると, 軽度難聴からも DEH が発現する可 能性も考えられなければならない.そしてこの発想の最 先端にあるのが対側型 DEH である. 対側型において, $\mathrm{DEH}$ は聴力正常な良聴耳に発症する。したがって, 先 行難聴の程度を中等度感音難聴まで拡大させたいといら のは，あくまで便宜的な発想である。しかしそらするこ とによって, 同側型 $\mathrm{DEH}$ が本態論的により正確に診断 されると考它られる。

上の議論は究極的に, DEH とメニエール病との区別, ないし異同論にまで発展する。これまで本邦のメニェー ル病研究において, 特発性発症が臨床診断の条件とされ てきたが，“では，メニエール病に打ける特発性とは何 か”について, DEH は改めて問いかけている.

本稿の要旨は, 1999年 8 月20～21日開催された，第26回金沢 医科大学神経科学セミナー(テーマ：めまいの基礎と臨床)にお いて講演した.

\section{参考文献}

1) Schuknecht HF : Delayed endolymphatic hydrops. Ann Otol Rhinol Laryngol $87: 743 \sim 748,1978$.

2 ) 亀井民雄, 野呂久公, 矢部 昂, 他: 一側性全壟の統計的 観察,ならびに若年性片側全血の特異性とメマイ疾患の好 発性について. 耳喉 $43: 349 \sim 358,1971$.

3 ) Tarkkanen $\mathrm{J}$ and Aho $\mathrm{J}$ : Unilateral deafness in children. Acta Otolaryngol (Stockh) $61: 270 \sim 278,1966$.

4) Everberg G : Unilateral anacusis. Acta Otolaryngol Suppl (Stockh) $158:$ 366 374, 1960.

5 ) Tieri L, Masi R, Ducci M, et al : Unilateral sensorineural hearing loss in children. Scand Audiol Suppl $30: 33 \sim 36$, 1988.

6 ) Lehnhardt E : Zur einseitigen Taubheit im Kindesalter. Arch Ohren Nasen Kehlkopfheilkunde 180:230 235, 1962.

7 ) 南立純一郎 : 片側高度神経難聴, 殊に原因不明の若年性片 側壟について. 日耳鼻 $66: 281 \sim 287,1963$.

8 ) Nadol JB Jr, Weiss AD and Parker SW : Vertigo of delayed onset after sudden deafness. Ann Otol Rhinol Laryngol $84: 841 \sim 846,1975$.

9 ) Wolfson RJ and Leiberman A : Unilateral deafness with subsequent vertigo. Laryngoscope $85: 1762 \sim 1766,1975$.
10) Schuknecht HF : Pathophysiology of endolymphatic hydrops. Arch Otorhinolaryngol $212: 253 \sim 262,1976$.

11) Schuknecht HF, Suzuka $Y$ and Zimmermann $C$ : Delayed endolymphatic hydrops and its relationship to Meniere's disease. Ann Otol Rhinol Laryngol 99 : 843 853, 1990.

12) Schuknecht HF : Neurolabyrinthitis; viral infections of the peripheral auditory and vestibular systems. Hearing Loss and Dizziness (ed by Nomura Y). pp 1 12, IgakuShoin, Tokyo, 1985.

13）亀井民雄, 石井英男, 中山杜人 : 若年性片側襲に遅発性に 発症するめまいについて一主として遅発性内リンパ水腫 症候群 (Schuknecht)一。耳鼻臨床 71 : 1245 1256, 1978.

14）渡辺行男, 麻生 伸, 水越鉄理 : 遅発性内リンパ水腫の検 討一とくに対側型内リンパ水腫の特徵について一. Equilibrium Res (Suppl) 5 : 152 157, 1989.

15) Kamei $T:$ Delayed vertigo. Vestibular Mechanisms in Health and Disease (ed by Hood JD). pp 369 374, Academic Press, London, 1978.

16) Hicks GW and Wright JW III : Delayed endolymphatic hydrops ; a review of 15 cases. Laryngoscope $98: 840 \sim$ 845, 1988.

17) Kamei $T$ and Matsuzaki $M$ : Delayed endolymphatic hydrops ; some statistical observations. Surgery of the Inner Ear (ed by Arenberg IK). pp 101 103, Kugler Publications, Amsterdam, 1991.

18）工藤祐弘, 二木 隆 : 対側型遅発性内リンパ水腫の聴力変 動について. Equilibrium Res $46: 297 \sim 303,1987$.

19）吉田友英, 橘田千秋, 木村 祐, 他: 遅発性内リンパ水腫 の統計的観察. Equilibrium Res $50: 294 \sim 297,1991$.

20）武田憲昭, 肥塚 泉, 西池季隆, 他: 遅発性内リンパ水腫 症例の臨床的検討. 日耳鼻 $101: 1385 \sim 1389,1998$.

21) Harcourt JP and Brookes GS : Delayed endolymphatic hydrops ; clinical manifestations and treatment outcome. Clin Otolaryngol $20: 318 \sim 322,1995$.

22）猪狩市世, 高橋正紘, 伊藤光子 : 遅発性内リンパ水腫 一症 例報告と統計的観察一. 耳喉頭頸 $60: 369 \sim 375,1988$.

23) LeLiever WC and Barber HO : Delayed endolymphatic hydrops. J Otolaryngol $9: 375 \sim 380,1980$.

24) Lambert PR : Delayed vertigo and profound sensorineural hearing loss. Laryngoscope $95: 1541 \sim 1544,1985$.

25）沢田正一, 竹田泰三, 柿木章伸, 他 : 遅発性内リンパ水腫 症例の検討. 耳鼻臨床 $88: 1129 \sim 1134,1995$.

26) Langman $\mathrm{AW}$ and Lindeman $\mathrm{RC}$ : Sensorineural hearing loss with delayed onset of vertigo. Otolaryngol Head Neck Surg $112:$ 540 543, 1995.

27) Karmody CS : Congenital deafness and episodic vertigo. Otolayngol Head Neck Surg 90 : 602 605, 1982.

28) Ylikoski J : Delayed endolymphatic hydrops syndrome af- 
ter heavy exposure to impulsive noise. Am J Otol 9 : 282 285, 1988.

29) Paparella MM and Mancini F : Trauma and Meniere's syndrome. Laryngoscope 93 : 1004 1012, 1983.

30) Clark SK and Ree TS : Posttraumatic endolymphatic hydrops. Arch Otolaryngol $103: 724 \sim 726,1977$.

31) Yaku Y and Komatsuzaki A : Ultrastructure of the vestibular sensory organs in delayed endolymphatic hydrops. Am J Otolaryngol $10: 336 \sim 341,1989$.

32）工藤祐弘，仙波哲雄, 二木 隆：遅発性内リンパ水腫の診 断と治療. 耳鼻臨床 補 $8: 208 \sim 216,1986$.

33) Aso $\mathrm{S}$ and Watanabe $\mathrm{Y}$ : Electrocochleography in the diagnosis of delayed endolymphatic hydrops. Acta Otolaryngol Suppl (Stockh) $511: 87 \sim 90,1994$.

34) Parnes LS and McClure JA : Rotatory recovery nystagmus; an important localizing sign in endolymphatic hydrops. J Otolaryngol $19: 96 \sim 99,1990$.

35）高橋正紘：遅発性内リンパ水腫. 耳鼻咽喉科・頭頸部外科 MOOK No. 7 (松永 亨編). 187 193頁, 金原出版, 東 京, 1988.

36) Kobayashi H, Ito M, Mizukoshi K, et al : The fluosemide VOR test for Meniere's disease. Acta Otolaryngol Suppl (Stockh) $468: 81 \sim 85,1989$.

37）渡辺 勈：厚生省研究班のメニエール病診断基準について. 耳鼻臨床 $69: 301 \sim 303,1976$.

38) Kitahara $M$ : Concepts of diagnostic criteria of Ménière's disease. Ménière's Disease (ed by Kitahara M). pp 3 12, Springer-Verlag, Tokyo, 1990.

39）亀井民雄, 石井英男, 大川卓男, 他 : 晚発性先天性迷路梅 毒の長期観察の一例. 日耳鼻 $79: 1629 \sim 1641,1976$.

40）吉本 裕：流行性耳下腺炎性感音難聴に罹患後, 遅発性に 発生した小児の反復性めまい. 耳喉 $57: 629 \sim 635,1985$.

41）工藤裕弘, 針谷しげ子, 二木 隆: 平均 10 年経過した若年 者の一側襲症例の平衡機能と遅発性内リンパ水腫の発現頻 度. Equilibrium Res Suppl $2: 99 \sim 103,1987$.

42) 水越鉄理, 将積日出夫, 渡辺行雄 : メニエール病の疫学. JOHNS $12:$ 1585 1589, 1996.

43) Stahle S, Arenberg IK and Stahle J : Incidence of Meniere's disease. Arch Otolaryngol $104: 99 \sim 102,1978$.

44）小松崎篤(代表）：めまいの診断基準化のための資料 ; メ二 エール病(1987年めまいの診断基準化委員会答申書). Equilibrium Res $47: 247 \sim 249,1988$.

45) Baloh RW : Dizziness, Hearing Loss, and Tinnitus. pp 169 170, FA Davis Co, Philadelphia, 1998.

46) Kemink JL and Graham MD : Hearing loss with deleyed onset of vertigo. Am J Otolaryngol $6: 344 \sim 348,1985$.

$\left(\begin{array}{l}\text { 原稿受付: 平成11年 } 9 \text { 月 } 3 \text { 日 } \\ \text { 原稿採択 : 平成11年11月 } 4 \text { 日 } \\ \text { 別刷請求先 : 亀井民雄 } \\ \text { テ371-0825 前橋市大利根町1-20-9 }\end{array}\right)$ 